\title{
A study on the sports educational zeal through the qualitative network analysis: Focusing on mothers of student athletes
}

\author{
Byung-Goo Lee \& Han-Joo Lee* \\ Yonsei University
}

\begin{abstract}
[Purpose] The purpose of this study was to investigate how the educational zeal of mothers with winter sports students in secondary schools appears on the network charts. [Methods] It lasted 28 days from February 6 to March 5, 2017. Starting with a description of the QNA, all interviews were recorded on a tape recorder to carry out the project. Data analysis were divided into four areas(Family, Friend, School, etc.) and 13 associative words(enthusiasm, intelligence, performance, entry, success, sacrifice, atmosphere, polarity, competition, vicarious, satisfaction, economic power, anxiety, stress) to attach associative word stickers according to color. [Results] As a result of inducing arbitrary interpretation of the network subject's educational network, it was possible to analyze the factors affecting mothers' sports education in three dimensions. In addition, although there is not much difference in areas around "I" on sports education charts, the distance between associative words and network charts has gradually moved away from the same person as their children go on to school. [Conclusions] The methodological significance of this study has been found to be very useful in visualizing an individual's educational network by utilizing qualitative network analysis and in understanding the characteristics associated with education.
\end{abstract}

Key words: Sports education, Qualitative network, Network chart, QNA, SNA, Winter sports, Mother

\section{서 론}

한국사회는 치열한 교육경쟁에 의해 야기된 부모의 지 나친 교육열이 사회적 문제로 대두될 때마다 교육전문 가들은 학력·학벌주의 타파, 학부모 의식 개혁과 입시정 책개선 등을 입버릇처럼 지적한다(Kim \& An, 2003). 특히 우리 정부는 지난 40 여년간 추진한 평준화 교육정 책을 지속해서 시행하나 여전히 우리사회의 교육열은 식을 줄 모른다.

그동안 교육사회학 학자들 사이에서 한국사회의 교육 열을 이해함은 물론 고유한 이론적 틀을 마련하기 위한 노력이 이루어져 왔다. 이에 대해 가장 활발한 논의를 펼 쳐온 $\mathrm{Oh}(2002)$ 는 한국사회의 교육열을 설명 할 수 있는

논문 투고일 : 2019. 04. 03.

논문 수정일 : 2019. 05. 06.

게재 확정일 : 2019. 05. 19.

* 교신저자 : 이한주(hlee@yonsei.ac.kr).
기존의 교육사회학적 이론을 검토한 결과, '교육출세론', '집단경쟁체제론', '경험확대공유론', '외국어자본론' 등의 네 가지 가설수준의 이론을 제시했다. 이어 $\operatorname{Kang}(2008)$ 도 한국사회의 교육열에 대한 이론화를 역시 모색하면서 '지위지향적 교육열', '가족주의적 교육열', '상징주의적 교 육열', '결과주의적 교육열' 등의 성향들로 나누어 설명하 고, 이러한 네 가지 성향의 교육열이 신분상승에 대한 옥 구와 맞물려 나타나고 있음을 주장했다. 반면 Lee(2011) 는 교육열을 '동기<인식<행 위<현상'으로 분류·파악했으 며, 교육열의 동기를 '자녀성취욕구'로 해석한 바 있다.

이로 인해 지금의 교육열은 긍정적인 의미로 해석하기 보다는 치맛바람, 과열된 사교육의 열풍, 지나친 입시경 쟁, 더 나아가 조기유학이나 기러기 아빠 등의 사회문제를 일으키는 부정적인 용어로 사용되고 있다(Ryu \& Hong, 2012). 이에 Choo(1999)는 학부모들이 자녀교육과 관련 하여 그들이 갖는 옥망으로서 결국 부모가 자녀의 학업을 
통해 대리만족하려는 것이라고 지적한다. 그러나 부모들의 열화가 우리나라 교육발전 및 사회발전의 원동력으로 작 용해 왔다는 점에서는 이견이 없다(Kim, 2003). 결국 부 모들의 교육열은 결국 한국 교육제도와 정책에 영향을 미 쳐 경제성장에 밑받침이 되는 인간자본을 형성하는데 기여 했다는 긍정적인 평가를 받기도 한다(Han \& Kim, 1990).

하지만 $\operatorname{Kim}(1992)$ 은 교육열이 교육받을 자녀의 열의 라기보다 교육을 기대하는 사람 즉, 학부모의 열의라는 점 을 강조하고 있다. 이는 부모의 높은 교육열이 사회적 조 건 속에서 형성된 자녀의 교육에 대한 부모들의 기대와 열 의에 기초하고 있다고 해석할 수 있다. 이에 An \& Kim (2005)은 교육열이란 자녀교육에 대한 부모의 열정으로 서 자녀에게 갖는 관심과 기대라는 무형의 자본과 지원 및 조력이라는 유형의 자본이 결합하여 긍정적인 내재적 가 치의 구현과 부정적인 외재적 가치의 추구라는 형태로 표출되는 내면의 심리적 행위라고 정의한다. 이외에도 사 회적 현상 혹은 개인의 심리적 동기 측면에서 교육열이 논 의되었으며, 연구자에 따라 학력 및 학벌 쟁취 현상 $(\mathrm{Oh}$, 2008 ), 자녀교육 경쟁열 (Park, 2009), 자녀에 대한 성취 옥구(Lee \& Kim, 2003), 사회적 욕망 혹은 교육에 대한 집착 에너지 (Kang, 2007) 등으로 정의되고 있다.

한편 부모는 자녀교육에 절대적인 영향력을 보이며, 매니저이자 후원자로서 다양한 역할을 한다(Sung \& Yoo, 2011). 유소년 골프선수의 스포츠자신감에 대해 연 구한 $\operatorname{Kim}(2018)$ 은 부모로부터 얻는 안정감과 같은 정서 적지지, 기술에 대한 피드백, 골프 관련 정보 및 필요비용 등을 제공한다는 측면에서 부모의 지지가 유소년 골프선 수의 자신감을 향상시킨다고 밝혔다. 이는 부모가 자녀에 게 가장 중요한 영향력을 행사하는 사람이며, 양육에 있어 서 가장 중요한 최초의 교육자이다.

이를 통해 자녀의 스포츠 활동을 통해 부모는 목표를 상 향 조정하고, 그 과정에서 타인에게 인정을 받음에 따라 열 성의 정도가 높아질 수 있다. 일례로 Chae(2008)은 우리 나라 쇼트트랙 선수들의 부모들을 대상으로 조사하였는데 부모의 열성적인 지원이 자녀들의 기술습득과정에 긍정 적인 영향을 미치고 있음을 밝힌 바 있다. 결국 부모의 열성 이 자녀가 엘리트 스포츠 선수로 진로를 결정하는데 중요 한 요소임을 의미한다.

이와 같은 현상은 부모의 정신적·물질적 지원이 자녀가 스포츠에 진지하게 입문하는 계기(Brustad, 1993; Cote, 1999)를 만들 뿐만 아니라 운동수행에도 영향(Holt,
Tamminen, Black, Sehn, \& Wall, 2008)을 미친다고 밝 히고 있다. 이러한 선행연구들은 공통으로 자녀들이 스포 츠에 참여하고 자신의 재능을 지속적으로 개발하기 위해 서는 부모의 지원이 주요함을 역설하고 있다. 이를 통해 '테니스 대디', '하키맘', '피겨맘'과 같은 신조어가 등장하 였고, 열성적으로 뒷바라지하는 부모들을 사회적 현상으 로서 접근하고 있다. 그러나 자녀 교육만큼은 아버지보다 는 어머니가 주도적이다(Sohn, 2000). 우리사회에서 자 녀교육은 부모 중에서도 특히 어머니가 주로 담당하고, 교육열 표출에서도 어머니의 역할이 결정적이다(Kim, 2003). 이는 결국 교육의 성과 여부가 어머니의 역 할임을 직·간접적으로 유추할 수 있다.

이에 대해 Sohn(2010)은 한.일 양국 어머니의 교육 열을 비교한 결과, 자녀교육에 대한 책임의식은 두 나라 모두 공통점을 보이고 있으나 우리나라 어머니들이 일본의 어머니들에 비해 '교육매니저'로서 정보수집과 자녀의 학 습적 측면을 지나치게 강조함을 밝혔다. 이에 Lee(2007) 는 교육열 표출에 있어 어머니의 역할이 결정적으로 작용 되고 있으며, '돼지엄마'란 신조어가 대표적인 사례라고 말 한다. 돼지엄마란 강남 교육정보의 전령사로서 자신의 자녀 교육에 자타가 공인하는 성공한 어머니를 일컬으며, 소위 명문대학에 입학하는 것을 최대의 덕목으로 삼는 어 머니들 사이에서 만나고 싶은 선망의 대상이다(Kim, 2013).

그럼에도 불구하고 한국사회의 교육현상을 이해하는데 교육열이 핵심적인 개념일 뿐 아니라 과거와 현재를 파악 하고 미래를 예견하는데 빠뜨릴 수 없는 현상이다(Lee, 2002). 이러한 현상은 이전부터 우리 어머니들이 '맹모삼 천지교'를 따르는 것을 하나의 미덕으로 삼아 자녀교육을 위해 자신들의 삶을 희생하는 것을 아름다운 모습으로 묘 사되었기 때문으로 해석할 수 있다(Kim, 2008). 이는 시 대와 상관없이 여전히 자녀의 교육에 있어서 어머니의 역 할이 매우 중요함을 의미하며, 동시에 자녀의 상급학교 진 학여부는 곧 어머니의 능력지표로서 작용하고 있음을 의 미한다.

이처럼 어머니의 능력은 스포츠 현장에서도 요구되는데 Chung \& Kim(1996)은 부친보다는 모친의 스포츠 권유 가 자녀의 입상경험이 높게 나타나며, 이러한 근본적인 원 인으로는 부친에 비해 선수로서 필요한 용구 및 기자재 지 원 그리고 실질적인 매니저로서 역할을 하기 때문이라고 한다. 이에 Park(2008)는 과거 자신은 여느 피겨맘처럼 아이와 온종일 같이 다니고 훈련시간에도 늘 링크장 안에 
서 대기하다 보니 다른 어머니들과 자주 접할 기회가 상 대적으로 많아 다른 코치의 정보나 훈련비용, 진학 등의 정보들을 자연스럽게 공유한 적이 있다고 말한다.

이어 Kim \& Lee(2001)도 국내 초등학교 스케이트 선 수들이 어려운 훈련을 이겨내는데 주요한 역할을 하는 사 람은 '어머니'이며, 많은 시간을 자녀의 훈련시간을 비롯한 모든 교육에 있어 지지자로서 열성을 보인다고 한다. 이를 통해 스포츠 교육열이란 스포츠와 교육열의 합성어로 자 녀가 하는 스포츠 활동을 지지하는 동시에 대리만족과 자 녀의 스포츠 커리어의 성공을 기원하는 부모의 열의로 정 의할 수 있다. 그러나 이러한 선행연구들은 스포츠 교육열 을 단순히 사회적 현상으로 해석하거나 경기력에 영향을 주는 요소로만 밝힐 뿐, 운동선수를 둔 어머니들의 교육 열을 깊이 있게 분석한 것이 아니기에 교육현상에 대한 연 구자료로서 미비한 면이 있다. 첫째, 선행연구의 대부분이 과도한 사교육 현상으로 인한 어머니들의 교육열에만 조 사하고 있다는 점이다. Jang(2014)은 목동 어머니들의 사 교육 현상과 상황적 구조 및 한계를 밝히고자 연구한 결 과, 과도한 사교육은 존재의 부재(不在)라는 근본적인 한 계를 가지고 있다고 밝혔다. 그러나 스포츠 교육열은 저 마다 진로가 결정된 상태에서 학부모와 자녀 모두 상급학 교 진학 또는 실업팀 취업이라는 공통된 목표를 갖고 있기 에 단순히 사교육을 통해 자녀의 학업증진을 목적으로 교 육열이 높은 어머니들과는 다르게 접근할 필요가 있다. 둘 째, 스포츠 교육열에 대한 부모들을 조사한 선행연구는 수 치화된 통계프로그램을 활용하여 사회적 관계를 파악하고 있어 교육열에 대한 구체적인 현상을 파악하는데 제한적 이다. 일례로 Lee et al. (2015)는 자녀가 리듬체조 선수로 활동 중인 학부모들을 대상으로 사회연결망(UCINET)을 통해 분석하였는데 네트워크 중앙성에 위치한 부모들의 자녀가 우수한 경기성적을 보인다고 밝혔다. 그러나 스포 츠 교육열은 경기력보다는 정보력과 밀접한 관련성을 보 여 사실상 온종일 스포츠매니저 역할을 병행하는 동계스 포츠 어머니들의 교육열을 폭넓고 깊이 있게 분석·이해하 기에는 충분하지 않다.

따라서 이러한 내용들을 기반으로 어머니의 교육열을 깊 이 있게 연구하기 위해 질적 네트워크 연결망으로 본 연 구를 분석하는데 적합하다고 판단했다. 이어 자료수집도 네 트워크 차트와 어머니들의 인터뷰 결과를 확장할 필요성 이 있다고 생각했다. 그러므로 이 연구에서는 동계 스포츠 종목에서 활약 중인 중등학교 학생선수들을 자녀로 둔 어
머니들 사이에서 스포츠 교육열을 사회적 관계중심으로 조사하고자 한다.

\section{연구목적}

본 연구의 목적은 중등학교 동계종목 학생선수를 둔 어 머니의 교육열이 네트워크 차트 상에서 어떻게 나타나는 가를 조사하는 것이다.

\section{연구문제}

첫째, 동계종목 학생선수를 둔 어머니의 스포츠 교육 열이 네트워크 차트에서 어떻게 구성되는가?

둘째, 동계종목 학생선수를 둔 어머니는 영역별 인식 에 대한 집단별 차이는 존재하는가?

\section{연구방법}

\section{네트워크 차트}

본 연구에 사용한 네트워크 분석도구는 질적연구방법 중 하나로 한 개인이 둘러싸고 있는 환경 인자 속에서 어 떠한 연결고리를 사용하여 타인과 관계를 형성하고 있 는지를 알아보는데 있다(Moon et al., 2008). 이에 Park (2008)은 질적 네트워크 분석 (이하 Qualitative Network Analysis, QNA)은 양적 네트워크 분석 (SNA, Social Network Analysis, SNA)을 기반으로 발전시킨 사회적 네트워크에 대한 질적 접근으로 이해될 수 있으 나 정형화된 형태나 공식이 있는 것은 아니라고 강조한 다.

또한 QNA를 활용한 실험적인 기법들을 개발하고 적 용해보는 시작단계에 있다고 보아도 무리가 아니며, QNA 와 $\mathrm{SNA}$ 의 가장 큰 차이점으로 사회적 네트워크가 구성 되는 네트워크 주체 (network ego) 즉, 중심이 되는 개인 의 정서적, 상황적인 특성도 중요한 고려대상이 될 수 있다 (Park, 2009). 이러한 차이점을 고려하여 본 연구에서도 $\mathrm{QNA}$ 의 특징과 장점을 극대화하는 방향으로 연구방향 을 설정하고 진행했다. 그리고 본 인터뷰 상황에서는 앞서 설명한 방법론을 토대로 다음의 세 단계로 실시했다. 〈Fig. 1〉는 본 인터뷰에 사용한 네트워크 차트이다. 


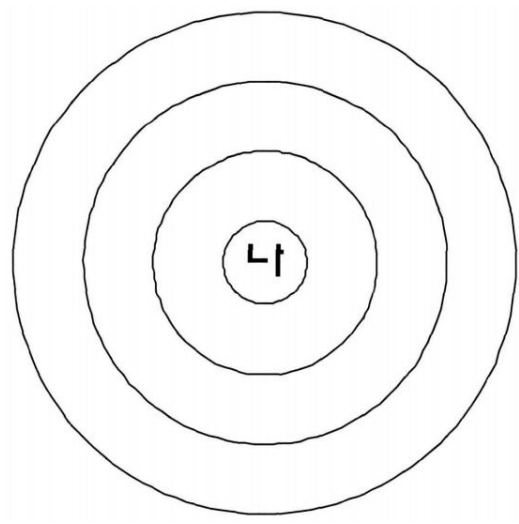

Fig. 1. Network chart

- 네트워크 차트 중심에 '나'를 위치시킨다.

- 나를 중심으로 4 개의 영역이 구분되는데 주관적 평 가에 따라 크기가 다르다.

- 13 개의 단어 스티커를 나눠 주고, 4 개 영역 가운데 해당되는 곳에 모두 붙이도록 한다.

이와 같은 단계를 통해 네트워크 차트를 완성했다. 그 리고 각 네트워크 차트는 연구 참여자 면담을 통해서 수 집되었으며, 인터뷰는 제한된 시간(90분 120분) 내에 이루어졌다.

\section{연구참여자}

본 연구에 참가한 연구 참여자들은 대한체육회 동계스 포츠 종목에 중·고등학교 선수등록이 된 자들을 자녀로 둔 어머니 28명을 최종 연구대상으로 선정했다. 지역선정은 타 지역에 비해 상대적으로 동계스포츠 학생선수들의 분 포가 많은 수도권으로 정했다. 그러나 어머니만을 대상으 로 연구가 진행되었기에 자녀의 성별 또는 운동기간, 부 모의 $\mathrm{SES}$ (사회경제적지위) 등의 요소는 전혀 고려하지 않았다. 일례로 연구에 참여한 참여자들 대부분이 종목에 따라 상급학교 진학 조건, 가계, 학력, 사회 지위 등이 비 슷했기 때문이다.

집단별 분류는 개인종목과 단체종목으로 분류했다. 상 대적으로 선수 수가 적고, 훈련장소도 고정적인 설상 종 목을 제외한 빙상종목 학생선수들로만 구성했다. 집단별 로 세부종목을 살펴보면, 개인종목에는 피겨스케이팅과 쇼트트랙, 스피드스케이팅 3종목을 단체종목에는 유일한 동계스포츠인 아이스하키가 최종 선별된 종목이자 집단
으로 선정했다.

\section{자료수집}

자녀가 재학 중인 학교단위에 따라 중학교와 고등학교 로 구분했다. 이에 〈Table 1〉에 제시한 인원에 따라 사전 에 동의를 얻고 인터뷰 내용을 녹취했다. 자료수집 기간 은 2017년 2월 6일부터 3월 5일까지 총 28일간 진행됐 다. 인터뷰가 진행된 장소는 빙상종목 학생선수들의 집중 적으로 몰려 있는 장소인 목동링크장, 고려대링크장, 태 릉선수촌링크장, 분당링크장, 의정부링크장등 총 5 곳의 아이스 링크장에서 이루어졌다.

Table 1. Grouping by school and sports

\begin{tabular}{|c|c|c|c|}
\hline \multicolumn{2}{|c|}{ Sports } & \multirow{2}{*}{$\begin{array}{c}\text { Middle School } \\
3\end{array}$} & \multirow{2}{*}{$\begin{array}{c}\text { High School } \\
3\end{array}$} \\
\hline \multirow{3}{*}{ Individual sports } & Figure & & \\
\hline & Speed & 3 & 3 \\
\hline & Short track & 3 & 3 \\
\hline Team sports & Ice Hockey & 5 & 5 \\
\hline
\end{tabular}

또한 연구 참여의 자율성을 사전에 공지하고, 개별면 담을 각각 실시하여 해당 내용을 모두 녹취·전사작업을 실시했다. 이에 따라 본 연구에 참가한 모든 연구 참여자 들은 인터뷰 시기와 장소와 다를 뿐, 대체로〈Fig. 2 〉와 같은 절차로 진행했다.

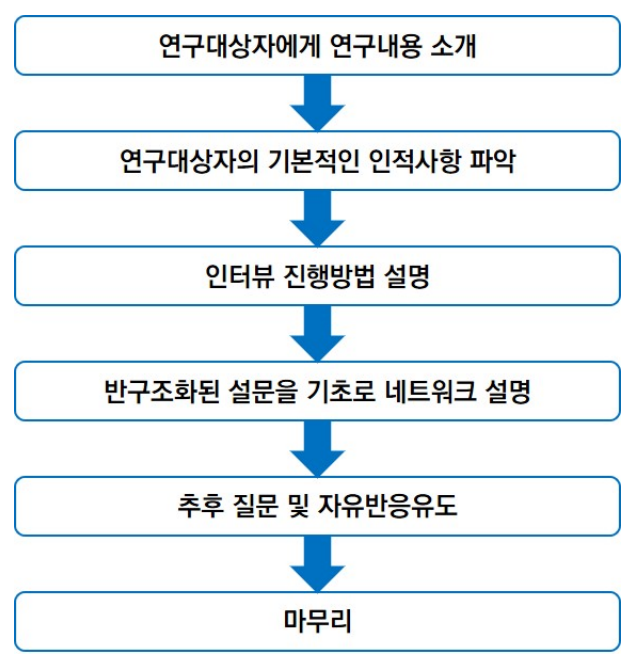

Fig. 2. Flow-chart 


\section{자료분석}

모든 연구 참여자에게 연구에 대한 설명과 함께 네트워 크 차트를 작성하도록 했다. 그리고 13 개의 연상단어 스 티커를 붙이도록 안내했다.

네트워크 차트는 빈칸을 모두 작성하기 보다는 연구 참여자와 관련된 어머니들을 떠올릴 수 있는 경우에만 이 름, 관계(학부모, 동창, 친구) 또는 직책(회장, 총무) 등을 구체적으로 표기하도록 설명했다.

한편 네트워크 차트를 완성하기 위해 본 인터뷰가 실시 되기 전, 동일한 조건의 파일럿 대상자를 3 인을 섭외하여 진행했다. 이를 통해 4가지 영역(Family, Friend, School, etc.) 과 13 개의 연상단어 (경제력, 만족감, 소속감, 발안 감, 압박, 성공, 경쟁, 분위기, 실적, 진학, 열성, 정보력, 희 생)를 구할 수 있었다. 〈Table 2)처럼 색으로 구분(colorcoded)되는 연상단어 스티커를 네트워크 주체가 적합하 다고 생각하는 영역 바깥쪽에 붙이도록 했다. 특히 붉은색 스티커에는 연구참여자의 부정적인 감정을 쉽게 파악될 수 있도록 했다. 이를 통해 네트워크 주체의 집중성과 타 인들과의 접근가능거리를 가시적으로 파악하고, 네트워 크 차트를 보면서 반구조화된 질문지를 중심으로 면담을 실시했다.

Table 2. Cognition-color and key word

\begin{tabular}{lc}
\hline \hline Cognition-color & Key word \\
\hline & enthusiasm \\
intelligence \\
performance \\
entry \\
success \\
sacrifice \\
atmosphere \\
\hline Negative-red & polarity \\
& competition \\
& vicarious satisfaction \\
& economic power \\
anxiety & stress \\
\hline \hline
\end{tabular}

또한 네트워크 주체의 집중성과 다른 어머니들 간의 접 근가능거리를 가시적으로 파악하고, 동시에 네트워크 차트 를 함께 보면서 반구조화된 질문지를 중심으로 면담이 이 루어졌다. 이어 2017년 7월 17일부터 29일까지 총 13일 간 연구참여자들에게 개별적으로 e-mail 또는 카카오톡
으로 연구결과를 전송하여 분석 및 해석에 대한 재평가 (member checking)를 하도록 요구했다.

\section{연구결과 1}

\section{가족}

본 연구의 참여자들 중 3 명을 제외한 전원이 가족을 제 1 선호영역으로 선택했다. 가족과 관련된 단어들 중 희생 이 가장 많았으며, 이어 성공, 경제력, 대리만족 등의 연 상단어들을 선호했다. 이에〈Table 3〉처럼 집단별로 제1 선호영역과 주요단어를 정리했다.

이처럼 집단과 상관없이 Family를 제 1 선호영역으로 선호했으며, 13 가지 연상단어 중 '희생'을 가장 많이 선택 했다. 그러나 '피겨-중등부'의 경우에는 School이 제1선 호영역으로 나타났다. 이러한 이유는 다른 동계종목들과 다르게 체 육특기자 신분으로 학교 운동부에 속해 있는 경 우가 드물며, 이로 인해 어머니가 체육교사와 직접 훈련 일정을 조율하거나 진학과 관련된 다양한 정보를 얻기 때 문으로 해석된다.

Table 3. First preference and key word

\begin{tabular}{lcc}
\hline \hline Classification & First preference & Key word \\
\hline $\begin{array}{l}\text { Individual - } \\
\text { middle school }\end{array}$ & Family (7/9) & $\begin{array}{c}\text { succeed, sacrifice, } \\
\text { economic power }\end{array}$ \\
\hline $\begin{array}{l}\text { Group - } \\
\text { middle school }\end{array}$ & Family (5/5) & sacrifice, success \\
\hline $\begin{array}{l}\text { Individual - } \\
\text { high school }\end{array}$ & Family (8/9) & $\begin{array}{c}\text { succeed, sacrifice, } \\
\text { economic power, } \\
\text { vicarious satisfaction, anxiety }\end{array}$ \\
\hline $\begin{array}{l}\text { Group - } \\
\text { high school }\end{array}$ & Family (5/5) & $\begin{array}{c}\text { sacrifice, economic power, } \\
\text { vicarious satisfaction }\end{array}$ \\
\hline \hline
\end{tabular}

\section{긍정적 인식}

인터뷰 결과, 자신의 가족에 대하여 매우 긍정적으로 이 야기했으며, 연상되는 단어로 '희생’을 선택했다. 동계스 포츠 특성상, 부모 중에 한 명은 자녀의 훈련 매니저 역할 을 맡아야하기에 본인을 포함한 가족구성원 모두가 희생 적인 삶을 살아가고 있다고 말한다. 그러나 예상과 달리, 어느 누구 하나 불평·불만을 표현하기보다는 응원하는 모 
습을 엿볼 수 있었다.

"누나가 가야금을 전공하고 있어요. 지금 예고를 다니고 있 는데 고2라 제가 픽업을 해줘야 해요. 근데 $\infty$ 이가 운동을 해야 한다고 하니까 본인은 괜찮다며 이해한다고 하더라구 요. $\cdots$ (중략) $\cdots$ 지금은 가족들 모두 많이 도와주고 있어요."(중 등부, 아이스하키 B)

"피겨는 링크장에서 모든 걸 해결해요. 보통. 그래서 운동하 고 있으면 잠깐 제 일을 보는 편이에요 $\cdots$ (중략) $\cdots$ 희생이라 볼 수 있죠. 근데 $\mathrm{OO}$ 가 잘되는게 부모의 역할 아닐까요? 물 론 오빠한테 미안하긴 한데 $\cdots$ 요새는 더 좋아해 하더라구요. 제가 뭐라 하질 않으니까..."(중등부, 피겨A)

"모든 고등학교 엄마들이 똑같지 않을까요? 일단 당장 대학 을 가야되니까...(중략)...우린 애가 하나라서 다른 형제들한 테 미안하거나 하진 않는데...(중략) $\cdots$ 아뇨, 주말엔 아빠가 나와요. 본인도 애가 운동하는걸 보구싶어 하기도 하구요..." (고등부, 쇼트트랙C)

대체로 자녀가 있는 가정에서는 형제·자매의 보이지 않 는 희생이 존재하나 운동선수로서 성공하기 위해서는 당 연히 어머니의 빈자리를 내어주는 형제애를 확인할 수 있 었다. 그리고 가족들 모두 자녀의 운동에 대해 지속적인 관 심과 응원을 하고 있으며, 희생은 가족으로서 당연한 것이 라 말하고 있다. 결국 이러한 가족의 암묵적인 지지는 단지 운동으로 성 공하기가 쉽지 않다는 것을 가족 모두가 인지 하고 있기에 가능한 걸로 해석된다.

\section{부정적 인식}

예상대로 동계스포츠 어머니들은 집단과 상관없이 '경제 력, 대리만족, 불안감 등의 부정적인 단어들이 많이 거론 됐다. 분석결과 이들 모두 자녀의 선수생활로 인해 경제적 으로 어려움을 겪고 있으며, 동시에 경기결과에 따라 대리 만족을 느끼고 있었다. 이러한 이유로 사춘기 자녀와 갈등 을 경험하고 있다는 어머니도 더러 있었다.

"피겨가 생각보다 경쟁이 심해요. 애네가 김연아 키즈라고 해서 그때 운동을 한 애들이거든요...(중략) $\cdots$ 네, 지금 상비 군인데 자질구레하게 돈이 많이 들어가죠. 계속 성적을 내야 되니까..."(고등부. 피겨 B)

"스피드는 다른 동계종목에 비해 돈이 많이 들어가진 않아 요. 훈련장소도 이동없이 여기서 운동을 하니 굳이 엄마들이 붙어다닐 필요도 없구요...(중략)..사실 저희가 기초생활수 급자에요. 많이 빠듯해요. (중략) $\cdots$ 애가 성공하지 못할까봐
불안하죠. 다른 집보다는 $\cdots$ 우리는 진짜 운동으로 성공을 해 야 하니까요."(중등부, 스피드C)

"당연히 감정 이입이 되죠. 애가 골을 넣으면 제가 넣은거 같 이 얼마나 기쁜데요. 그 맛에 쫓아다니는 거에요...(중략).. 아뇨, 전엔 아이스하키 자체를 몰랐어요. 애가 하니까 알게 된거지..."(고등부, 아이스하킽)

자녀의 경기결과에 따라 어머니들이 느끼는 감정은 상 이하게 나타나고 있었다. 더욱이 동계종목 특성상, 경제 적인 부담도 있어 일부 가정에서는 생계의 어려움도 동 시에 느끼고 있었다. 이들은 공통적으로 '성공'에 대한 갈 망은 자녀 못지않게 어머니에게도 확인할 수 있었다. 이 로 인해 좋은 결과를 가져오지 못할 경우, 결국 자녀와 부 모 간의 보이지 않은 갈등도 예상할 수 있다.

\section{친구}

학부모들의 교육열은 사회계층에 따라 형성되는데 이 들은 자녀 교육을 이유로 하나의 정보망을 형성하며, 이 를 '부모주의'라고 한다(Oh, 2008). 이는 '돼지엄마'란 신 조어를 통해 알 수 있는데 결국 어머니의 정보력에 따라 자녀의 진학도 결정된다고 봐도 과언이 아니다.

인터뷰 결과, 동계스포츠 학부모들은 자녀의 훈련시간 동안 동료 학부모와 같이 보내는 시간들이 많았으며, 특 히 운동과 관련된 다양한 정보들을 공유하고 있었다. 더 구나 단체종목과 달리, 개인종목은 어머니가 지도자를 선 택하고 결정하기에 정보 공유 측면에서 동료 어머니와의 관계가 매우 중요하다.

\section{긍정적 인식}

집단과 상관없이 동계스포츠 어머니들에게 친구란 자 녀의 운동과 관련하여 정보를 공유하는 이들을 의미한 다. 이에 운동관련 정보는 물론 부족한 학업을 보충하기 위 해 동네 어머니들과 유대관계를 이어가고 있으며, 일부 어 머니들은 링크장에서 허비하는 시간을 아끼기 위해 과외 교사까지 소개를 받아 링크장에서 짜투리 공부를 시키고 있었다. 이에 연상단어로 '정보력'을 가장 많이 선호했다.

"친구 엄마들한테 과외정보를 많이 얻는 편이에요. 이번 학 기부터 성적이 안되면 e-school인가? 그걸 들어야 한다고 들 어서요 $\cdots$ (중략) $\cdots$ 그래서 초등학교때 친했던 학부모들한테 연락해서 추천받고 있어요."(중등부, 아이스하키D) "거의 링 크장에서 시간을 보내니까 주변 학부모들한테 정보를 많이 
얻는 편이에요 $\cdots$ (중략)..공부나 개인레슨이나 $\cdots$ (중략)..네, 보통 링크장으로 올 수 있는 분으로 소개받고 있어요. 다들 공유하는 편이에요."(고등부, 피겨A)

"공부는 아무래도 애 오빠 친구 부모한테 많이 묻는 편이에 요‥(중략) $\cdots$ 네, 오빠는 운동을 하지 않아요. 그래서 물어보 기가 다른 학부모보단 낫죠 $\cdots$ 경쟁자가 아니니까 $\cdots$ (중략)... 아뇨, 과외선생 소개 빼고는 다른 걸로 묻진 않아요."(고등부, 스피드C)

학생선수의 학습권 보장을 목적으로 지난 2016년 9월 부터 전국 학교운동부 운영학교에 e-school을 시행하고 있 다(Kim et al., 2016). 이에 동계스포츠 학부모들 사이에 서는 해당 정책에 대한 정보를 주변에서 얻고 있었으며, 특히 부족한 학업 보충을 위해 사교육을 시키는 모습들을 쉽게 볼 수 있었다.

\section{부정적 인식}

친구와 관련되어 부정적인 단어로는 '경쟁'을 많이 선택 했다. 동계스포츠 특성상, 비슷한 시기에 운동을 같이 시 작하여 지금까지도 인연을 이어가는 경우를 현장에서 많 이 볼 수 있었다. 그래서 연구참여자들은 인터뷰 내내 “바 닥이 좁다'라는 표현을 자주 썼다. 그러나 상급학교 진학 에 필요한 메달획득을 목표로 자녀의 스포츠 교육이 이루 어지고 있기에 경쟁은 불가피하다. 이는 단순히 어머니들 간의 보이지 않은 시기와 질투가 존재하는 것으로 해석할 수 있다.

"이번에 대입으로 간 애들이 고작 2명이에요...(중략)...상비 군을 해도 특기자로 대학가기가 사실상 어렵죠. 그래서 다들 눈치 보면서 입시원서를 쓰는 걸로 알고 있어요 ‥(중략)...아 뇨, 엄마들이 원서 쓰죠. 코치님은 운동만 가르치세요."(고등 부, 쇼트트랙B)

"이번에 5 명 입학했어요. 나머지는 은퇴에요. 소속이 없으면 선수등록이 안되거든요 ‥(중략)...그래서 입시체육도 고민하 고 있어요. 근데 대학에서 메달반영을 빙상으로 뭉떵 묶어서 반영하니 서로 경쟁이 심각해요. 요새 엄마들끼리도 서로 입 시 관련해서 정보공유를 따로 하지 않아요. 서로 실력들을 뺀히 아니까."(고등부, 스피드C)

"서울에 스피드 하는 학교가 없어요 $\cdots$ (중략) $\cdots$ 아 00 고등학 교에서 1 명인가 받이줐는데 이젠 입학을 거절하죠. 사실상 없다고 보면 돼요. 그래도 스피드는 경기도 주변에서 받고 있 어서 다행인데 문제는 우리 집에서 멀으니 통학하기가 쉽지 않아요...(중략)..진학 문제는 코치들도 어떻게 할 수 없어서 보통 엄마들이 알아서 정보를 얻어요..."(중등부, 스피드C)
정해진 정원 (TO)에 따라 상급학교로 입학할 수 있는 인원이 제한적이어서 경기 외적으로 경쟁이 치열하다. 특 히 다른 스포츠에 비해 적은 수의 특기자를 선발하는 특 성상, 지도자의 정보력보다는 어머니들의 정보력이 결정 적 한 방으로 작용하고 있었다. 이로 인해 아이스 링크장 공간 내에 어머니들 간의 보이지 않는 경쟁이 존재하고 있음을 확인할 수 있으며, 가계 지출의 또 다른 부담으로 작용되고 있음을 유추할 수 있다.

\section{학교}

한국사회는 소위 '학벌사회’로 불릴 만큼 학력이 매우 중 요하며, 특히 대학입시를 둘러싼 경쟁적인 교육열은 가정 과 사회 전체에 지대한 영향을 미친다(Kim, 2004). 이는 학군에 따라 부동산 가격이 결정되는 현상을 통해 간접적 으로 유추할 수 있다.

하지만 Lee(2003)은 학부모의 과잉된 교육열이 학교 와 교사의 대응부족이라 해석했으며, 오히려 조장하고 있 다고 지적한다. 운동부를 운영하고 있는 일선 학교현장에 서는 체 육특기자제도를 통해 학생선수를 관리·지도하고 있다. 그리고 동계스포츠 역시, 지정학교에서 학업과 운동 을 병행하고 있으며, 학생선수 신분에 맞는 다양한 혜택 들을 누리고 있다. 그러나 이들의 관리문제를 이유로 체 육교사들이 담당업무를 기피하고 있어 종목 육성학교가 해마다 감소하고 있다.

\section{긍정적 인식}

인터뷰 결과, 학교와 관련된 연상단어로 '진학, 실적, 분위기' 등이 자주 언급됐다. 이는 학생선수 신분을 이어 가기 위해서는 반드시 상급학교 진학에 필요한 실적이 뒷 받침되어야 하기 때문이다.

"과천에 피겨가 많이 몰려 있어요. 여기가 메카에요. 피겨 좀 한단 아이들은 전부 과천에 올 수 밖에 없어요. 여기에 다 있 거든요 $\cdots$ (중략)..네, 학교도 근방에 피겨 특기자로 받아 주 는 학교가 있어서 이리로 많이 운동하러 와요."(중등부, 피겨 A)

"단체종목이라 그 해 에이스들이 몰리는 팀에 가는게 아무래 도 대학 가기에 좋죠. 그래서 이 학교로 온 거에요."(고등부, 아이스하키 D)

"다른 학교도 알아보고 했는데 아무래도 장비가 많고 해서 
여기로 결정했죠. 코치쌤도 열의도 있으시고 해서 $\cdots($ 중략)... 아뇨, 아직 창단팀이라 성적은 좋지 않아요. 그래서 시에서 지원도 있고 애들 또래에서 잘하는 아이들이 여기에 몰려 있 으니 애네들이 3학년이 되면 나아지지 않겠어요?"(중등부, 아이스하키E)

“보시는 것처럼 쇼트트랙은 다 함께 훈련해요. 그래서 훈련 분위기가 중요해요 $\cdots$ (중략) $\cdots$ 아뇨, 옮길 수는 있죠. 근데 굳 이 그러진 않죠. 학교랑 연계되어 있으니...그래서 처음 시작 할 때 잘 선택해야 해요."(중등부, 쇼트트랙C)

학교를 선택하는 어머니들의 결정은 종목에 따라 상이 하게 나타났다. 개인종목의 경우, 학교의 지원보다는 훈련 장소와 인접한 학교를 선호하는데 반해 단체종목은 특정 선수에 따라 학교를 선택하는 경향이 뚜렷했다. 이에 어머 니들은 학교에 대해 자녀의 선수생활을 이어가기 위해 주 변환경과 여건을 고려하는 동시에 단체종목은 성적과 직 결되는 학교 선택까지 고려해야 하는 어려움이 존재했다.

\section{부정적 인식}

지나친 입시경쟁으로 인해 일부 어머니들은 학교에 대해 '압박'으로 느끼고 있었다. 이로 인해 어머니와 학교 간의 보이지 않는 완력 싸움이 연출되기도 한다.

"아무래도 특기자 신분이 아니니 훈련이 있거나 대회가 있으 면 학교에서 전화가 와요. 수업일수다 뭐다 해서 교육청에서 제재가 있다고 $\cdots$ (중략) $\cdots$ 체육교사랑 이야기를 많이 하려 하 는데 장시호 사건 이후에 다들 피하는 분위기에요."(중등부, 피겨C)

“체육교사가 정말... 학교가 갑이죠. 우리 같은 운동부 입장 에서는 $\cdots($ 중략) $\cdots$ 서울에는 중학교 팀이 없어요. 그래서 실적 이 어느정도 나와야 대회에 출전할 수 있어요. 선수등록도 할 수 있구요...(중략)..우리 아이 통해서 실적은 다 얻으면 서 특기자 혜택은 주지 않으니..."(중등부, 스피드C)

"입시 때마다 전쟁이에요. 운동부가 학교에서 골칫덩어리로 취급받으니 응당 받아주는 팀도 없어요. 시교육청이나 시체 육회에 창단 시켜달라고 탄원을 넣어도 받아줄 학교가 없다 며 그냥 피하죠...(중략)...그러니 학교가 갑이죠. 그래서 실 력이 비슷한 집들끼리 서로 눈치를 보게 돼요. 힘들죠. 해마 다..."(고등부, 스피드A)

“학교에서 지원이 없어요. 다 우리가 부담하죠. 그런 상황에 서도 학교에서는 실적이 나오길 바라죠...(중략)...아무래도 다른 운동부랑 비교 당하잖아요. 은근 압박하죠. 시합 때 보 면 교장이나 교감이 한 마디 하고 가잖아요."(고등부, 아이스 하키B)
정해진 장소에서 훈련을 해야 하는 동계스포츠 특성 상, 학생선수의 관리·운영은 사실상 어려운 면이 있다. 이 로 인해 상급학교에서는 이들의 입학을 기피하고 있으며, 이러한 피해는 고스란히 유망주들에게 돌아가고 있다. 이 는 단순히 어머니들이 자녀의 선수생활을 이어가기 위해 학교와 상대해야 하는 수고와 어려움을 동시에 경험 해석 할 수 있다.

\section{기타}

네 번째 영역은 연구참여자가 스스로 선택한 사회집단이 기에 긍정적인 반응이 대다수 차지했다. 주로 포춘텔러, 목 사, 스님 등 신앙과 관련된 분들이 언급됐다. 이를 통해 치 열한 경쟁 상황 속에서 어머니 스스로 심적 위안으로 삼아 무언의 압박에서 벗어나고자 하는 모습을 엿볼 수 있다.

“포춘텔러 아시죠? 포춘텔러...(중략)..자주는 아니구요. 가 끔 답답할 때 가는 편이에요. 중요한 결정을 해야 될 때 $\cdots$ (중 략) $\cdots$ 아니요, 교회 다녀요. 사실 아이가 운동하고 가게 됐어 요. 너무 답답하고 매 긴장도 되니까..."(중등부, 쇼트트랙C)

“목사님하고 많이 대화해요. 요새 더 그러네요...(중략)..1년 전에 애가 수술을 했어요. 그때부터 기도를 많이 드리게 됐 어요"(중등부, 아이스하키D)

"작년부터 무당집(=포춘텔러)을 찾고 있어요. 애랑 자꾸 부닺 히게 돼서요. 부상도 오구 실력도 느는것 같지 않아 보이 구 $\cdots$ (중략)..계속 시켜야 되나 고민이 되죠. 자꾸 경쟁은 심 해지고 돈도 계속 들어가구...그래서 찾게 되는 것 같아요." (중등부, 스피드A)

자녀의 훈련과정이 매 순간 긴장의 연속이기에 어머니 들은 자연스럽게 종교의 힘을 빌리는 모습들을 엿볼 수 있었다. 특히 일부 어머니들은 답답한 마음에 무속신앙에 의지하는 경향이 뚜렷하게 보였다. 이는 단순히 미신을 통 해 자녀의 성공을 기원하는 행위로 볼 수도 있으나 어머 니들의 복합적인 불안요소를 회피하려는 몸부림으로 해 석할 수 있다.

이외에도 네트워크 차트에서 직장동료, 블로그 모임 등 도 언급되었다.

\section{연구결과 2}

본 연구는 중등학교 동계스포츠 종목에서 활약 중인 
학생선수들을 자녀로 둔 어머니들의 스포츠 교육열을 사 회적 관계중심으로 조사·분석했다.

이상의 연구결과를 종합적으로 정리해보면, 연구참여 자 모두 가족, 친구, 학교, 기타 등의 영역들이 스포츠 교 육열에 영향을 미친다고 밝혔다. 그리고 13 개의 연상단어 마다 긍정적 또는 부정적 요소들을 내포하고 있었다. 그러 나 집단별 질적 네트워크 차트 일례들은 서로 다른 모습 들을 보이고 있다. 〈Fig. 3 6〉는 집단 별로 유사한 특징 들을 정리한 것이다.

이처럼 연상단어에서 어머니들의 교육열 인식들의 차 이점을 확인할 수 있었으며, 특히 자녀의 학년이 높아질 수록 어머니들의 스포츠 교육 네트워크도 명확하게 나타 났다. 그리고 매니저로서 어머니의 역할이 다방면에서 점 차 능숙해짐을 확인할 수 있었다.

〈Fig. 3〉의 분석결과, 중등부-단체종목의 어머니들은 남편에 대한 의존도가 가장 높았다. 이는 다른 동계종목 들에 비해 운동에 필요한 장비가 많은 종목 특성상, 배우 자가 무거운 장비를 정기적으로 운반 또는 관리를 해줘야

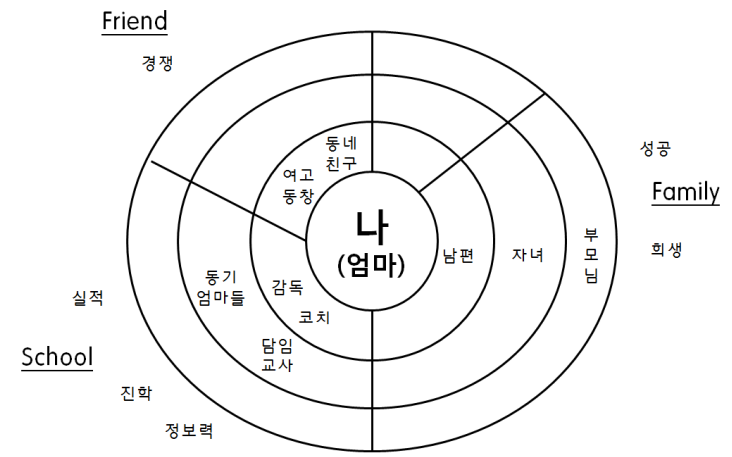

Fig. 3. QNA' chart of Middle S. - Group S.

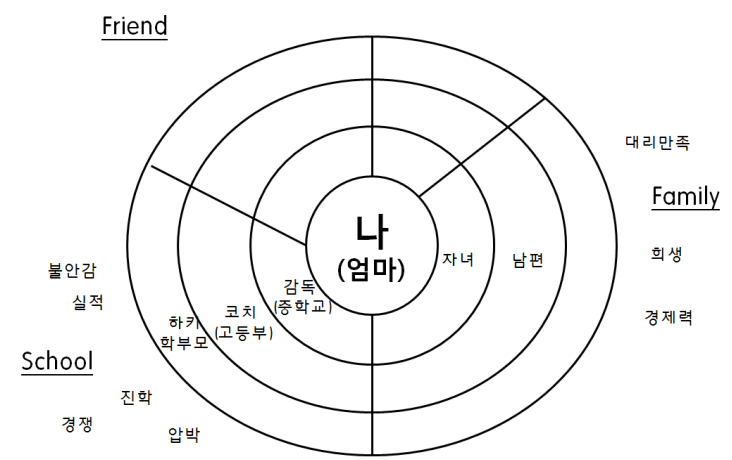

Fig. 5. QNA' chart of High S. - Group S.
하기에 여느 동계 스포츠 종목 아버지들보다 교육에 대 한 관여도가 높다. 이로 인해 어머니들은 다른 종목과 달 리, 자녀의 운동만큼은 남편과 가장 많이 공유하는 것으 로 나타났다.

또한 훈련시간이 고정적인 단체종목 특성상, 개인종목 에 비해 상대적으로 시간 여유가 많아 동네친구나 여고 동창과 잦은 만남을 이어가면서 친목을 다지고 있으나 한 편으로는 자녀에 대한 보이지 않는 경쟁의식을 갖고 있 었다. 이는 자녀가 아이스하키를 하는 가정 대다수가 소 위 학군이 좋은 지역 즉, 강남이나 목동의 자녀들이기 때 문으로 해석된다.

〈Fig. 4〉의 분석결과, 중등부-개인종목 역시 단체종목 과 마찬가지로 가족영역이 우선순위로 나타났으며, 남편 과 자녀 순으로 친밀도를 형성하고 있었다. 그리고 단체 종목과 달리, 지인들에 대한 친밀도가 높았는데 이러한 이유를 살펴보면, 개인레슨으로 훈련하기 때문이다.

하지만 단체종목에 비해 부정적인 연상단어가 많이 나 타났는데 원인을 살펴보면, 보통 개인종목의 어머니들은

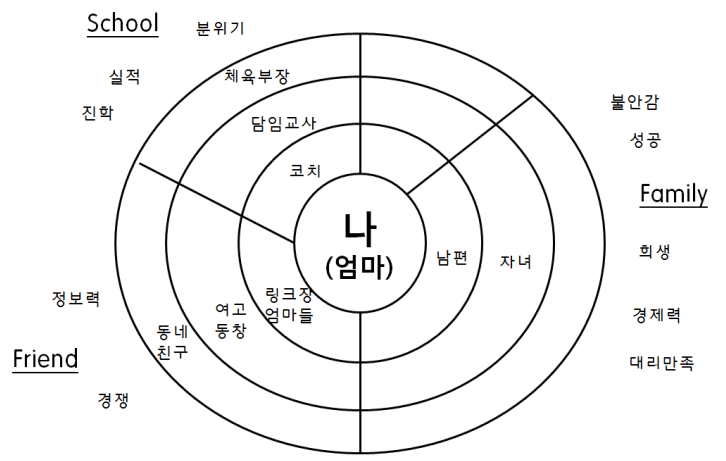

Fig. 4. QNA' chart of Middle S. - Individual S.

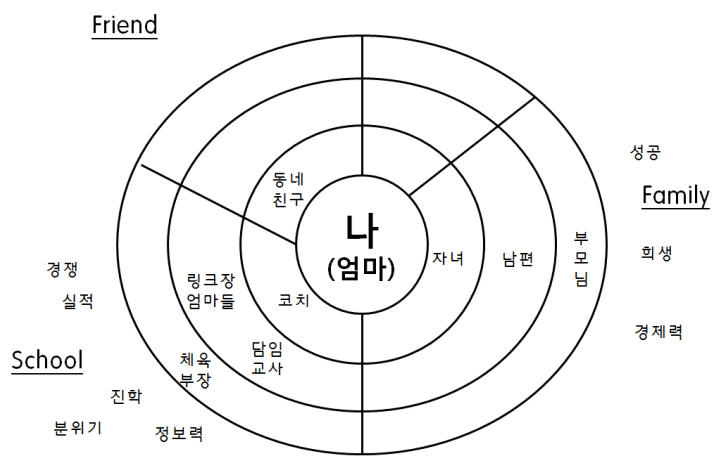

Fig. 6. QNA' chart of High S. - Individual S. 
다음 훈련 일정 때문에 링크장에 대기하는 시간이 길었 다. 이로 인해 자녀의 훈련이나 경기 내용을 실시간으로 보면서 때론 대리만족을 느끼지만 반대로 자녀가 기대만 큼 성장하지 보여주지 못할 때마다 미래에 대한 불안감도 자녀와 동일하게 느꼈다. 더욱이 지켜보는 어머니는 자녀 의 매니저를 자처해야 하기에 경제활동 즉, 맞벌이가 현 실적으로 불가능함에 따라 남편의 경제적 능력에만 의존 해야 한다는 어려움이 존재한다. 독특한 점은 피겨 종목의 어머니들은 카니발을 개조하여 운전하고 있었다. 이러한 이유를 살펴보면, 자녀의 훈련 장소가 매번 고정적이지 않 아 이동 중에라도 최대한 자녀의 휴식을 보장하기 위해서 어쩔 수 없는 선택이라고 말한다.

〈Fig. 5〉의 분석결과, 고등부-단체종목의 어머니들은 스포츠 교육에 있어 자녀에 대한 의존도가 가장 높았다. 이 는 상급학교 진학의 굴레에서 자유로운 중등부와 달리, 고등부 어머니들은 상급학교 진학에 대한 압박-불안 때문 에 자녀의 눈치를 보게 된다. 결국 표면적으로 자녀가 우선 순위라 말하고 있으나 가장 오랜 기간 신뢰관계를 형성한 옛 지도자의 경륜에 의지하려는 모습을 보였다. 그러나 중 등부와 달리, 고등부에는 네트워크 차트 상에서 주변 인 물에 대한 거리가 멀어졌다. 이러한 현상은 시간이 지나면 서 자녀의 훈련 스케줄 즉, 훈련 외적인 시간이 늘어남에 따라 만남의 횟수가 줄어들어 하키 학부모와 유유상종(類 類相從)하며 자녀에게 필요한 레슨이나 모임을 통해 자신 의 스포츠 교육열을 형성·해소하는 것으로 나타났다.

〈Fig. 6〉의 분석결과, 고등부-개인종목의 어머니들도 교육에 있어 자녀에 대한 의존도가 가장 높았다. 이는 상 급학교 진학을 이유로 어머니들이 자녀의 눈치를 보기 때문이다. 그러나 중등부와 달리, 담임교사에 대한 친밀도 이유는 다르게 설명하고 있다. 체육특기자 신분임에도 불 구하고 개인종목이란 이유로 코치나 체 육교사가 아닌 어 머니가 대회출전과 관련된 행정적인 처리를 사실상 도맡 아야 하기 때문이다. 이에 따라 이 집단의 어머니들은 담 임교사와 상당한 친밀도를 보였다.

이상의 집단별 네트워크 차트 일례 결과를 통해 가장 많이 선호한 '가족' 영역에는 네트워크 주체의 집중성이 다 를 뿐, 자녀와 아버지를 공통적으로 언급하고 있다. 그리 고 중등부의 경우, 고등부에 비해 '담임교사'에 대한 친밀 도가 높았는데 이러한 근본적인 이유는 최근 실시하고 있는 'e-school' 영향이라 해석된다.

또한 종목에 따라 어머니들의 우선순위가 다르게 나타
났는데 개인종목의 경우, '가족-친구-학교' 순으로 어머 니들의 우선순위가 결정되었으나 단체종목의 경우에는 '가 족-학교-친구' 순으로 차순위에서 다르게 나타났다. 이는 종목의 연관성과도 관련성이 있으며, 특히 개인종목 어머 니들의 경우에는 학교보다는 지인에 통해 운동이나 학업과 관련된 정보를 많이 얻고 있었다.

더불어 동일한 연상단어들을 확인할 수 있었다. 그러나 학교단위에 따라 어머니들은 영역을 달리 인식했다. 중등 부의 경우, 네 영역 모두 긍정적·부정적 영향을 미친다고 인식했으나 고등부는 가족과 학교만 영향을 미칠 뿐, 친구 와 기타는 별다른 인식을 보이지 않았다. 이는 자녀의 학년 이 승급할수록 어머니의 정보망이 보다 구체적이고 실효성 있는 관계형성을 선호하고 있음을 알 수 있다.

\section{논의 및 결론}

이 연구의 목적은 중등학교 동계종목 학생선수를 둔 어 머니의 교육열이 네트워크 차트에서 어떻게 나타나는가 를 조사하는 것이다. 연구결과에 근거하여 다음과 같은 결 론을 도출했다. 첫째, 어머니들의 네트워크 차트는 '가족', '학 교', '친구', '기타'로 입체적으로 나타났다. 둘째, 스포츠 교 육열 차트 상에서 '나'를 중심으로 영역별 차이는 크게 없 으나 연상단어와 네트워크 차트 거리가 자녀의 진학에 따 라 동일인물들이 점차 멀어졌다.

이 연구 진행과정에서 알게 된 점은 질적 네트워크 방법 (QNA)이 키워드 사례 연구를 모아 편집하거나 주요 포커 스 그룹으로 인터뷰 할 때, 같은 효과를 가질 수 있다고 보 았다. 그러나 키워드 연구와 개별적 인터뷰를 진행해 본 결 과, 연구주제에 여러 각도로 볼 수 있다. 특히 방법론적 특 성을 알 수 있었는데 연구참여자들은 네 가지 영역(가족, 친구, 학교, 기타)으로 네트워크 차트를 완성하도록 하여 이를 바탕으로 반구조화 면담을 실시하고, 동계종목 중등 학교 학생선수들을 둔 어머니들을 중심으로 스포츠 교육 열을 주는 요인들을 분석할 수 있었다.

결론적으로 동계종목에 선수등록이 된 중·고등학교 학 생 선수 자녀를 둔 어머니들의 스포츠 교육열에 하나의 지 표가 될 수 있다는 사실을 알 수 있었다. 특히 종목, 학교 단위, 개인-단체 스포츠에 따라 다양한 교육열을 보일 수 있음이 나타났다. 그러나 다른 요인들에 비해 경제력 또는 학군 등은 큰 영향력을 보이지 않았다. 오히려 진학, 경기 
실적, 훈련장 $(=$ 분위기 $)$ 등이 어머니들의 스포츠 교육열 에 영향을 주는 주요인으로 분석됐다.

이에 따라 이 연구의 방법론적 의의는 교육열을 네트 워크로 분석함은 물론 스포츠 교육열을 질적 네트워크를 적용하여 해석한 점이다. 질적 네트워크는 동계 종목에 선 수등록이 된 중·고등학교 학생 선수 자녀를 둔 어머니의 교육열에 대한 내용을 차트로 들어나게 한 후, 이를 보면서 설명했다. 그러나 면담으로 이루어진 것에 비해 입체적으 로 네트워크 주체를 둘러싼 타인들과의 관계들을 더 알 수 있었다.

그럼에도 불구하고 연구과정에서 아쉬운 부분은 제한된 시간 동안 충분한 라포형성 과정 없이 짧은 만남을 통해 준 비한 모든 질문 내용들의 답을 유도하기에는 진행 과정에 서 다소 미흡한 부분이 있었다. 더욱이 주어진 시간 제약 으로 인해 연구대상자들의 생각을 키워드로 듣는 것만으 로 만족해야 했다. 그러므로 본 연구를 통해 미흡한 부분들 은 후속연구를 통해 제언하도록 하며, 질적 네트워크의 유 용성을 확인할 수 있었다는 점에서 연구의 다른 의미성을 되새겨본다.

오늘날 나타나고 있는 가족주의는 이기주의적이고 파 편적이며, 이러한 근본적인 원인으로는 과거와 달리 자녀 에게 모든 것을 투자하는 강력한 가족주의가 교육열을 더 욱 상승시키기 때문이다(Kim, 2014). 이로 인해 자녀의 교육을 핑계로 조기유학, 학군 등의 교육과잉 현상들이 사 회적 문제로 대두되고 있다. 더욱이 글로벌 시대에 맞춰 스포츠 조기유학을 선택하는 경우가 해마다 증가함에 따라 향후 이러한 현상도 깊이 있게 살펴볼 필요가 있다.

본 연구의 의의는 질적 네트워크 분석을 활용하여 개인 의 교육적 네트워크를 가시화하고, 이를 토대로 교육열과 관련된 특성을 파악하는데 있다. 이는 중등학교 동계 스포 츠 종목 학생선수를 둔 어머니의 스포츠 교육열을 해석하 였기에 연구 자체만으로 가치성을 가지고 있다. 따라서 질적 네트워크 방법을 앞으로 좀 더 보완하여 다양한 연구 부분에 적용한다면, 어머니들의 스포츠 교육열뿐만 아니 라 스포츠를 통해 발생되는 다양한 현상들을 심도 있게 분 석·파악하는데 유용한 도구가 될 것이다.

\section{참고문헌}

An, W. H., \& Kim, K. S. (2005). The investigation of the parent's education fever by social capital in family. Secondary Institute of Education, 53(1), 29-50.

Brustad, R. J. (1993). Who will go out and play? Parental and psychological influences on children's attraction to physical activity. Pediatric Exercise Science, 5(3), 210-223.

Chae, J. H. (2008). Analysis on the formation of parents' supporting enthusiasm toward their elite short-track athletes. Ph.D. Dissertation, Yonsei University.

Choo, B. S. (1999). The enthusiasm for education of collective conformity and vicarious satisfaction. The Korean Society for sociology of Education, 9(1), 17-30.

Chung, Y. L. \& Kim, H. S. (1996). Influences of parents on socialization into the role of athletes. Korean Journal of Sociology of Sport, 5, 97-112.

Cote, J. (1999). The influence of the family in the development of talent in sport. The Sport Psychologist, 13(4), 395-417.

Han, J. S., \& Kim, S. H. (1990). Awareness of modern Korean education. Seoul: Chungabook.

Holt, N. L., Tamminen, K. A., Black, D. E., Sehn, Z. L., \& Wall, M. P. (2008). Parental involvement in competitive youth sport settings. Psychology of Sport and Exercise, 9(5), 663-685.

Jang, Y. J. (2014). Making bonsai trees of Mokdong mothers: Understanding the contextual structure and limitations of private education for children. The Journal of Anthropology of Education, 17(1), 159-195.

Kang, C. D. (2007). The study on social historical change process and feature in the university entrance system of Korea. The Journal of Research in Education, 28, 83-113.

Kang, C. D. (2008). A social historical study on the Korean paranoid educational fervor and status desire. The Korea Educational Reveiw, 14(2), 5-32.

Kim, H. B. (1992). Ethnographic study on parents' involvements in schooling of their children. Ph.D. Dissertation, Seoul National University.

Kim, J. M., \& Lee, J. Y. (2001). The process forming the selfactualizational enthusiasm of elementary school skate athletes' mother. Korean Journal of Sociology of Sport, 14(2), 351-360.

Kim, K. K. (2003). Educational zeal and youth unemployment in Korea. Korean Journal of Educational Research, 41(4), 87105.

Kim, K. S., \& An, W. H. (2003). An analysis of research trends in Korean education sociology. The Korean Journal of Sociology of Education, 2003 Summer Conference, 81-98.

Kim, O. C., Lim, S. W., \& Cheon, W. J. (2016). The actual con- 
ditions and future challenges of e-school managing system to protect studying-student athletes' the right to learn. Korean Journal of Sociology of Sport, 29(2), 41-65.

Kim, S. H. (2013). Gangnam mom's Information Technology: Gangnam mom-style education road map that designs a child's future. Seoul: Booklife.

Kim, S. H. (2008). A study on the bibliotherapy for developing children's social competence. Journal of Korean Library and Information Science Society, 39(2), 213-226.

Kim, S. Y. (2018). The effects of parents' support on sport selfconfidence and exercise commitment in female golf players. The Korea Journal of Sports Science, 27(4), 335-345.

Kim, W. B. (2014). The enthusiasm for education in Korea. Seoul: Orbis Sapientiae.

Lee, H. J. (2002). Understanding Korean kindergarten education. Seoul: Kyoyookbook.

Lee, J. G., \& Kim, K. S. (2003). A comparative study on conceptions of 'education fever.' Korean Journal of Educational Research, 41(3), 191-214.

Lee, J. G. (2011). Only when you know the passion for education can you see Korean education. Seoul: Idambooks.

Lee, K. H., Lee, H. J., Son, N. R., \& Lee, J. H. (2015). Who knows Who? Homophily in parental networks of Korean phythmic gymnasts. The Korean Journal of Physical Education, 54(4), 69-79.

Lee, M. K. (2007). A discourse on education: An analysis of the attitude of middle-class Korean mothers on the education of their children. Korean Journal of Sociology of Education, 17(3), 159-181.

Moon, K. S., Kim, H. C., Kim, J. Y., \& Lee, M. J. (2008). International comparison of the socialization process of adolescents through network analysis. Seoul: Korea Institute for
Youth Development.

Oh, O. H. (2002). The enthusiasm for education in Korean society. Seoul: Kyoyookbook.

Oh, O. H. (2008). Searching for causes of educational gap: Beyond school, toward family and society. The Korean Journal of Sociology of Education, 18(3), 111-133.

Park, H. G. (2009). Competition over children's education and The 'Full-Time Mother' Identity in Korean middle class families. Journal of Korean Women's Studies, 25(3), 5-33.

Park, M. H. (2008). Put the wings of dream on the child's talent. A message of dream and hope from figure skating queen Kim Yu-na's mother Park Mi-hee! Seoul: Polabooks.

Park, S. Y. (2008). A study on the socialization process of adolescents through the analysis of quality network. Seoul: Korea Institute for Youth Development.

Park, S. Y. (2009). A study on the socialization of American adolescents through qualitative network analysis. The Journal of Anthropology of Education, 12(1), 173-201.

Ryu, J. H., \& Hong, E. J. (2012). Parental roles and parent-child relationships of separated families. Journal of Open Parent Education, 4(1), 39-59.

Sohn, S. Y. (2000). Generational gaps between adolescents and their parents in understanding school life. Studies on Korean Youth, 11(2), 129-152.

Sohn, S. Y. (2010). A comparative study of attitudes in educating children between Korean mothers and Japanese mothers: Evaluation of own culture and foreign culture by those who lived in both countries. The Women's Studies, 79(2), 37-80.

Sung, C. H., \& Yoo, S. J. (2011). The component and profile of parental social support in youth sport. Korean Journal of Physical Education, 50(1), 83-92. 


\section{질적 네트워크 분석을 통한 스포츠 교육열 연구: 동계종목 중등학교 학생선수를 둔 어머니들을 중심으로 \\ 이병구 · 이한주(연세대학교)}

[목적〕 이 연구의 목적은 중등학교 동계종목 학생선수를 둔 어머니의 교육열이 네트워크 차트에서 어떻게 나타나는가를 조사하는 것이다. 〔방법) 인터뷰가 진행된 2017년 2월 6일부터 3월 5일까지 총 28일간 진행 됐다. 이어 연구참여자가 집중적으로 몰려 있는 아이스 링크장에서 인터뷰를 했으며, QNA 작성에 대한 설명 을 시작으로 모든 면담 내용들을 녹음기로 녹취하여 전사작업을 실시했다. 수집된 자료는 네 영역(Family, Friend, School, 기타)과 13개의 연상단어(경제력, 만족감, 소속감, 불안감, 압박, 성공, 경쟁, 분위기, 실적, 진학, 열성, 정보력, 희생)로 구분하여 색(color)에 따라 연상단어 스티커를 붙이도록 했다. (결과〕 네트워크 주체의 교육적 네트워크에 대한 자의적 해석을 유도한 결과, 어머니들의 스포츠 교육열에 영향을 주는 요인들 을 입체적으로 분석할 수 있었다. 이어 스포츠 교육열 차트 상에서 '나'를 중심으로 영역별 차이는 크게 없으나 연상단어와 네트워크 차트 거리가 자녀의 진학에 따라 동일인물들이 점차 멀어졌다. (결론) 이 연구의 방법론 적 의의는 질적 네트워크 분석을 활용하여 개인의 교육적 네트워크를 가시화하고, 이를 토대로 교육열과 관련 된 특성을 파악했다.

주요어: 스포츠 교육열, 질적 네트워크, 네트워크 차트, QNA, SNA, 동계 스포츠, 어머니 